\title{
Kajian Prosedur Pemindahan Arsip: Studi Kasus di Bank Indonesia
}

\author{
Fitri Susiani \\ Chongqing Three Gorges Vocational College, China
}

\begin{abstract}
This paper describes the procedure for transferring records carried out by Bank Indonesia. Transfer of records is one part of the shrinking program archive. Transfer of records is important to do to protect records that have a use value and to avoid stacking records. The data used in the study are primary data and secondary data. Primary data were obtained from observations or participatory observations, indepth interviews with records managers, as well as studies of archival policies issued by Bank Indonesia. The secondary data in the form of an assessment of library materials. The conclusion obtained from this paper is the transfer of records at Bank Indonesia using two methods, namely conventional methods and application-based methods. Guidelines for moving records have also been referring to international standards, namely ISO 15489-2016. The facilities and infrastructure used in the transfer of records are also in accordance with archival standards with adequate capacity. In carrying out the activities of the shrinking of the archive was not found significant obstacles.
\end{abstract}

Submitted: $21 / 11 / 2019$

Received: 22/01/2020

*Correspondence: Fitri Susiani fitrisusiani@gmail.com

KEYWORDS:

procedures, transfer, records

\section{INTISARI}

Makalah ini mendeskripsikan prosedur pemindahan arsip yang dilakukan Bank Indonesia. Pemindahan arsip merupakan salah satu bagian dari program penyusutan arsip. Pemindahan arsip penting untuk dilakukan guna melindungi arsip yang memiliki nilai guna dan menghindari menumpuknya arsip. Data yang digunakan dalam penelitian berupa data primer dan data sekunder. Data primer diperoleh dari hasil pengamatan atau observasi partisipasi, in-depth interview dengan pengelola arsip, serta kajian terhadap kebijakan kearsipan yang dikeluarkan oleh Bank Indonesia. Adapun data sekunder berupa pengkajian terhadap bahan-bahan pustaka. Kesimpulan yang diperoleh dari makalah ini adalah pemindahan arsip di Bank Indonesia menggunakan dua metode, yaitu metode konvensional dan metode berbasis aplikasi. Pedoman pemindahan arsip juga telah mengacu pada standar internasional, yaitu ISO 154892016. Sarana dan prasarana yang digunakan dalam pemindahan arsip pun telah sesuai standar kearsipan dengan kapasitas memadai. Dalam pelaksanaan kegiatan penyusutan arsip pun tidak ditemukan kendala signifikan.
KATA KUNCl: prosedur, pemindahan, arsip

\section{CITE THIS ARTICLE:}

Susiani, Fitri. (2019). Kajian Prosedur Pemindahan Arsip: Studi Kasus di Bank Indonesia . Jurnal Diplomatika, 3 (1), 38-51. 


\section{PENDAHULUAN}

Arsip merupakan rekaman kegiatan yang tercipta dari kegiatan dilaksanakan. Arsip hanya dapat tercipta satu kali, yaitu pada saat kegiatan berlangsung. Menurut perundang-undangan, arsip memiliki definisi sebagai rekaman kegiatan atau peristiwa dalam berbagai bentuk dan media sesuai dengan perkembangan teknologi informasi dan komunikasi yang dibuat dan diterima oleh lembaga negara, pemerintah daerah, lembaga pendidikan, perusahaan, organisasi politik, organisasi kemasyarakatan, dan perseorangan dalam melaksanakan kehidupan bermasyarakat, berbangsa, dan bernegara.

Berdasarkan fungsinya dalam operasional institusi maupun perorangan, arsip dibagi menjadi dua yaitu arsip dinamis (record) dan arsip statis (archives). Arsip dinamis merupakan arsip yang secara langsung masih digunakan dalam penyelenggaraan administrasi organisasi. Sedangkan arsip yang memiliki nilai guna kebuktian dan kesejarahan disebut juga arsip statis (archives). Arsip statis tidak lagi dipergunakan secara langsung dalam proses perencanaan, pelaksanaan, hingga penyelenggaraan administrasi sehari sehari sebuah organisasi.

Sejalan dengan laju dinamika kehidupan sebuah bangsa, ruang lingkup kegiatan administrasi negara dan pembangunan akan terus mengalami peningkatan. Akibatnya, volume arsip bertambah dengan cepat dan dapat menimbulkan pelbagai masalah, seperti keterbatasan penyediaan anggaran, tenaga, ruangan, dan perlengkapan serta pengelolaannya.

Pada prinsipnya, dalam pengelolaan arsip, tidak seluruh rekaman kegiatan berupa arsip disimpan permanen. Hanya arsip yang memiliki nilai guna berkelanjutan, sedangkan arsip yang tidak memiliki nilai guna berkelanjutan akan dimusnahkan. Pemusnahan arsip ini memberi peluang tersedianya tempat penyimpanan dan pemeliharaan yang lebih baik terhadap arsip-arsip yang memiliki nilai guna. Pemusnahan arsip merupakan salah satu aktivitas dalam program penyusutan arsip.

Program penyusutan arsip akan berdampak signifikan terutama bagi lembagalembaga negara yang menghasilkan arsip dengan volume besar. Penyusutan membantu dalam menangani keterbatasan kapasitas ruang simpan dan efektivitas proses penemuan kembali. Lembaga negara yang menghasilkan volume arsip berkapasitas besar ialah lembaga yang memiliki arsip yang berkaitan dengan kenegaraan seperti Bank Indonesia. Bank Indonesia adalah lembaga yang bertanggungjawab atas kebijakan terkait keuangan (kebijakan moneter) di Indonesia. Bank Indonesia memiliki tujuan tunggal, yaitu mencapai dan memelihara kestabilan nilai rupiah.

Hingga saat ini, Bank Indonesia memiliki unit penyimpanan arsip, yaitu Sentral Khazanah Arsip (SKA) yang berada di kantor pusat maupun di setiap kantor perwakilannya. Kantor Pusat Bank Indonesia di Jakarta memiliki SKA sebagai sarana penyimpanan arsip dari setiap satuan kerja di setiap departemen. Berdasarkan fakta tersebut, Bank Indonesia memerlukan adanya program penyusutan arsip untuk mengatasi permasalahan yang timbul sebagai akibat dari adanya penumpukan arsip. Salah satu kegiatan penting dalam penyusutan adalah pemindahan arsip.

Berdasarkan latar belakang tersebut, makalah ini berfokus pada pertanyaan penelitian: bagaimana pelaksanaan kegiatan pemindahan arsip yang dilakukan oleh Bank Indonesia? 


\section{METODE PENELITIAN}

Makalah ini merupakan hasil penelitian kualitatif dengan pendekatan deskriptif naratif, yaitu mendeskripsikan tahapan pemindahan arsip. Lokus dari penelitian adalah Bank Indonesia. Pengumpulan data dilakukan dengan pengamatan atau observasi partisipasi, in-depth interview, dan kajian pustaka.

1. Observasi partisipasi, yaitu penulis ikut berpartisipasi dalam kegiatan kearsipan di Bank Indonesia seperti pemindahan arsip, peminjaman arsip, penemuan kembali, pemusnahan arsip, dan lain sebagainya. Selain itu, penulis juga melakukan pengamatan terhadap sistem pengelolaan, kinerja pegawai serta berbagai prosedur dalam pelayanan kearsipan;

2. In-depth interview, narasumber yang diinterview yaitu top, middle, dan low menajer yang dapat dilakukan kepada arsiparis, manajer bidang, staff manajer, serta pegawai yang ada di Bank Indonesia. Sebelum melaksanakan wawancara, penulis membuat daftar pertanyaan terlebih dahulu terkait dengan permasalahan yang ingin ditanyakan kepada narasumber;

3. Kajian pustaka, dilakukan dengan cara mempelajari, mengutip teori-teori yang ada serta mendalami dari sejumlah buku dan literatur sebagai referensi mengenai pemindahan arsip.

\section{HASIL DAN PEBAHASAN}

Kearsipan di Kantor Pusat Bank Indonesia diorganisasi dengan asas campuran, yaitu kombinasi antara asas sentralisasi dan asas desentralisasi. Asas desentralisasi diterapkan ketika arsip masih bersifat dinamis aktif. Pengelolaan arsip dinamis aktif berada pada satuan kerja atau unit pengolah (UP) masing-masing. Ketika arsip telah memasuki masa inaktif atau memiliki retensi diatas tiga tahun maka tanggungjawab pengelolaannya berada di unit kearsipan sehingga disebut asas sentralisasi.

Arsip dapat dikatakan memasuki fase inaktif dan dipindah ke unit kearsipan atau SKA setelah 3 tahun masa aktif. Hal ini berbeda dengan arsip terjaga yang ada di Bank Indonesia. Arsip terjaga dapat dikategorikan sebagai arsip vital Bank Indonesia yang dikuatkan oleh Bank Indonesia. Arsip terjaga adalah arsip negara yang berkaitan dengan keberadaan dan kelangsungan hidup bangsa dan negara yang harus dijaga keutuhan, keamanan, dan keselamatannya (Arsip Nasional RI, 2009, 3). Apabila didasarkan pada SE No. 18/125/INTERN tanggal 30 Desember 2016 tentang Manajemen Dokumen Bank Indonesia, arsip terjaga Bank Indonesia merupakan arsip vital yang berkaitan dengan eksistensi dan kelangsungan operasional maupun manajerial institusi yang harus dijaga keutuhan, keamanan, dan keselamatannya. Arsip terjaga tersebut berisi tentang ketentuan-ketentuan mengenai penetapan kebijakan yang dikeluarkan oleh Bank Indonesia (wawancara dengan Indun Nusantari, Manajer Unit Pemeliharaan \& Penggunaan, tanggal 1 Maret 2018). Adapun contoh dari arsip terjaga meliputi: arsip penentuan mengenai suku bunga, penentuan mengenai Giro Wajib Minimum (GWM), penentuan jumlah uang beredar, dan lain sebagainya. Oleh karena arsip terjaga tidak memiliki masa aktif, maka unit kearsipan atau SKA Bank Indonesia berhak menarik arsip tersebut dari unit pengolah untuk disimpan di unit kearsipan Bank Indonesia. Apabila unit pengolah membutuhkan arsip tersebut, maka dapat mengajukan memorandum untuk peminjaman arsip ke unit kearsipan atau SKA BI.

Kantor Pusat Bank Indonesia terdiri dari 31 departemen dari lima (5) bidang. Berdasarkan analisis organisasial, terdapat ratusan satuan kerja pada masing-masing departemen. Setiap satuan kerja atau disebut dengan unit pengolah, mengolah arsipnya 
secara mandiri untuk kemudian dipindahkan ke Sentral Khazanah Arsip setelah masa aktifnya selesai. Arsip dinamis inaktif dari seluruh unit pengolah atau satuan kerja yang berada di kantor pusat disimpan di unit kearsipan atau disebut dengan Sentral Khazanah Arsip Kantor Pusat (SKA KP). Berdasarkan SE No. 18/125/INTERN tanggal 30 Desember 2016 tentang Manajemen Dokumen Bank Indonesia, Unit Kearsipan Kantor Pusat (selanjutnya disingkat UKKP) adalah unit kerja yang mempunyai tugas dalam pengaturan, pengembangan, dan pembinaan kearsipan di Bank Indonesia serta pengelolaan Sentral Khazanah Arsip (SKA) kantor pusat. Sentral Khazanah Arsip Kantor Pusat merupakan pusat penyimpanan arsip atau unit kearsipan Kantor Pusat Bank Indonesia (KPBI). Volume arsip dan perkembangannya di Bank Indonesia dapat dicermati pada tabel berikut:

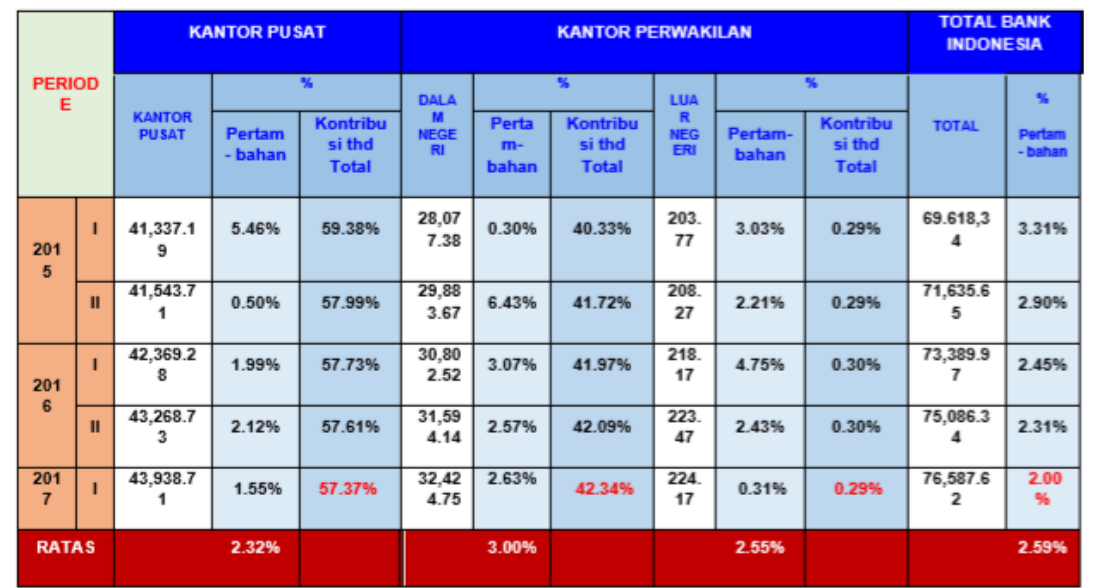

Tabel 1. Perkembangan Pertambahan Jumlah Dokumen Bank Indonesia Periode 2015 Semester I - 2017 Semester I

\begin{tabular}{|c|c|c|c|c|c|c|c|c|}
\hline \multirow{3}{*}{ Uraian } & \multicolumn{6}{|c|}{ Jumlah Dokumen } & \multirow{2}{*}{\multicolumn{2}{|c|}{ Total Dokumen }} \\
\hline & \multicolumn{3}{|c|}{ Kantor Pusat } & \multicolumn{3}{|c|}{ Kantor Perwakilan } & & \\
\hline & $\begin{array}{l}\text { Satker } \\
\text { KPBI }\end{array}$ & $\begin{array}{c}\text { SKA di } \\
\text { Divisi Arsip }\end{array}$ & $\begin{array}{c}\text { Jumlah } \\
\text { KP }\end{array}$ & Dalam Negeri & $\begin{array}{c}\text { Luar } \\
\text { Negeri }\end{array}$ & $\begin{array}{c}\text { Jumlah } \\
\text { KPw }\end{array}$ & Total & $\wedge \%$ \\
\hline $\begin{array}{c}\text { Posisi Awal } \\
\text { (30 Juni 2017) }\end{array}$ & $16,112.71$ & $27,826.00$ & $43,938.71$ & $32,424.75$ & 224.17 & $32,648.92$ & \multicolumn{2}{|c|}{$76,587.63$} \\
\hline Pertambahan & $1,990.59$ & 722.97 & $2,713.56$ & $1,378.75$ & 35.70 & $1,414.45$ & $4,128.01$ & $5.39 \%$ \\
\hline Pemusnahan & $(435.28)$ & (985.33) & $(1,420.61)$ & (573.14) & $(35.00)$ & $(608.14)$ & $(2,028.75)$ & $-2.65 \%$ \\
\hline $\begin{array}{c}\text { Pemindahan ke } \\
\text { SKA }\end{array}$ & (722.97) & $\cdot$ & (722.97) & $\cdot$ & - & $\cdot$ & (722.97) & $-0.94 \%$ \\
\hline $\begin{array}{l}\text { Posisi Akhir } \\
\text { (31 Des 2017) }\end{array}$ & $16,945.05$ & $27,563.64$ & $44,508.69$ & $33,230.36$ & 224.87 & $33,455.23$ & $77,963.92$ & $1,80 \%$ \\
\hline
\end{tabular}

Tabel 2. Posisi Dokumen Bank Indonesia Tahun 2017 Semester II

Berdasarkan tabel 1 dan 2, dapat diketahui perkembangan volume arsip di Bank Indonesia pada tahun 2015 hingga 2017 terus mengalami peningkatan. Bank Indonesia, dengan data tersebut, dapat menganalisis pertumbuhan arsip setiap tahun dan memprediksi kapasitas ruang simpan arsip di unit kearsipan (wawancara dengan Ahmad Nadjamudin, Manajer Unit Data \& Laporan, tanggal 23 Februari 2018).

Oleh karena tidak seluruh arsip disimpan permanen, maka dalam proses pengelolaannya perlu dilakukan seleksi arsip. Seleksi arsip dilaksanakan pada program penyusutan arsip. Program penyusutan arsip meliputi 3 kegiatan, yaitu pemindahan arsip dari unit pengolah ke unit kearsipan, memusnahkan arsip yang tidak memiliki nilai guna berkelanjutan, dan menyerahkan arsip yang berkaitan dengan pembangunan nasional ke Arsip Nasional Republik Indonesia.

Seiring dengan operasional kegiatan-kegiatan Bank Indonesia yang cukup kompleks, peningkatan volume arsip yang diciptakan oleh Bank Indonesia juga perlu diperhatikan. Pada tahun 2017 semester kedua volume arsip di Sentral Khazanah 
Arsip Kantor Pusat Bank Indonesia mencapai 44,508.69 M'. Oleh sebab itu, kapasitas ruang simpan harus disesuaikan dengan perkiraan pertumbuhan arsip setiap tahunnya. Penyesuaian dilakukan untuk mengantisipasi over capacity tempat penyimpanan arsip inaktif dan arsip statis di Sentral Khazanah Arsip (SKA). Dengan demikian, program penyusutan arsip merupakan solusi utama dari masalah penumpukan arsip. Makalah berfokus pada kegiatan pemindahan arsip sebagai salah satu kegiatan dari program penyusutan arsip. Pemindahan arsip yang dilakukan oleh Bank Indonesia dilakukan dengan 2 metode, yaitu metode konvensional dan berbasis aplikasi.

\section{Pemindahan Arsip dengan Metode Konvensional}

Pemindahan arsip inaktif dilakukan oleh unit pengolah ke unit kearsipan. Unit Pengolah (selanjutnya disebut UP) merupakan unit kerja pencipta dokumen dan arsip yang bertugas dan bertanggung jawab mengelola dokumen dan arsip. Sedangkan Unit Kearsipan Kantor Pusat (UKKP) adalah unit kerja yang bertugas dalam pengaturan, pengembangan, dan pembinaan kearsipan di Bank Indonesia serta pengelolaan Sentral Khazanah Arsip (selanjutnya disebut SKA) di kantor pusat.

Arsip yang dipindahkan dalam bentuk berkas. Pemindahaan berkas tersebut dilakukan melalui pemberitahuan (notifikasi) pada aplikasi Bank Indonesia Records Management System (selanjutnya disebut BI-RMS), kategori arsip terjaga Bank Indonesia, atau dengan adanya reorganisasi.

Arsip yang dipindahkan ke SKA harus memiliki retensi atau usia simpan diatas 3 tahun, misalnya 10 tahun atau bahkan permanen. Selain berdasarkan retensi, pemindahan arsip ke SKA dilakukan ketika ruang penyimpanan arsip di UP telah penuh, namun dengan ketentuan divisi arsip BI melakukan pemeriksaan langsung dan mengkonfirmasi kebenaran tempat penyimpanan di UP. Untuk arsip yang memiliki retensi dibawah 3 tahun yang disimpan di SKA akan mengikuti prosedur pemusnahan di SKA. Selain faktor retensi, jumlah arsip yang akan dipindahkan ke SKA minimal 10 berkas. SKA tidak akan menerima arsip dengan jumlah kurang dari 10 berkas.

Tahapan pemindahan arsip dengan metode konvensional dapat dicermati pada bagan berikut:

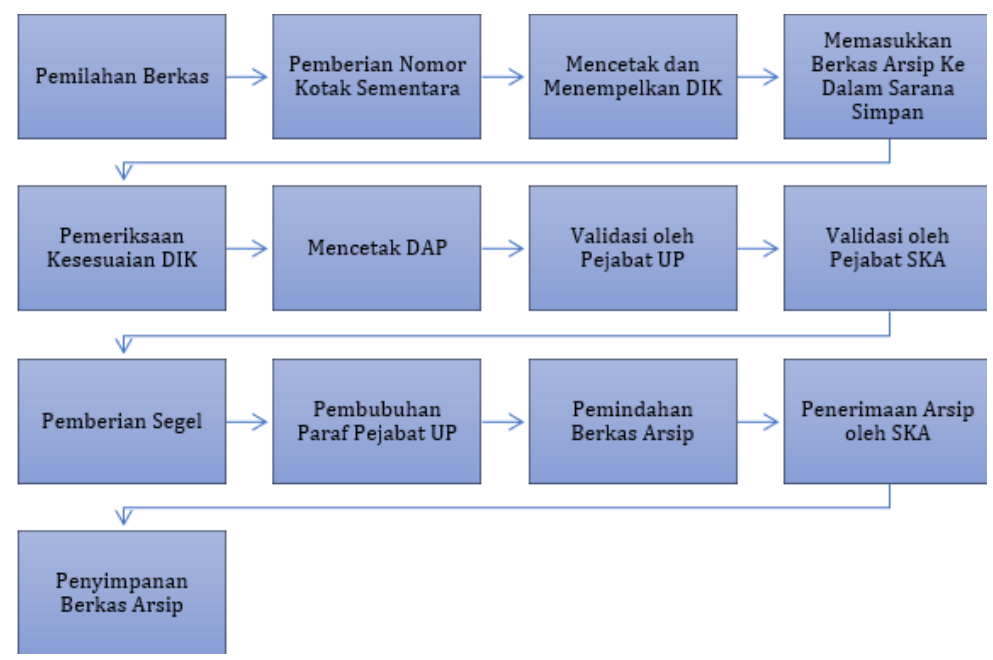

Bagan 1. Alur Pemindahan Arsip

a. Pemilahan berkas arsip, dilakukan melalui aplikasi BI-RMS. Aplikasi tersebut akan otomatis memunculkan pemberitahuan apabila arsip telah melampaui masa retensi 3 tahun. Pemberitahuan tersebut memuat jumlah arsip dan daftar berkas arsip yang harus dipindahkan. Selain melalui aplikasi BI-RMS, Bank Indonesia 
juga memilah berkas secara manual. Pemilahan manual diberlakukan untuk arsip yang belum diinput ke aplikasi BI-RMS, misalnya arsip yang tercipta sebelum tahun 2013. Pada prinsipnya, pemilahan arsip melalui aplikasi BI-RMS dan secara manual sebenarnya tidak jauh berbeda. Pemilahan arsip dilakukan berdasarkan usia arsip yang dipindahkan harus memiliki retensi diatas tiga (3) tahun. Perbedaan mendasar ada pada pemberitahuan untuk melakukan pemindahan;

b. Pemberian nomor kotak sementara, pemberian nomor sementara dimulai dari nomor 1. Pemberian nomor kotak dilakukan sebelum arsip memperoleh nomor penyimpanan dari unit kearsipan atau Sentral Khazanah Arsip;

c. Mencetak dan menempelkan Daftar Isi Kotak (selanjutnya disebut DIK), untuk berkas arsip yang dipindahkan melalui aplikasi BI-RMS, DIK secara otomatis akan tercetak. Namun, untuk arsip yang dipindahkan secara manual, DIK dibuat secara manual sesuai dengan format yang berlaku;

d. Memasukkan berkas arsip ke dalam sarana simpan, Berkas arsip yang akan dipindahkan dimasukkan ke dalam kotak arsip, untuk arsip yang berbentuk folder, compact disk (CD), kaset, cartridge, flash disk, dan bentuk arsip lainnya yang dapat dimasukkan ke dalam kotak arsip. Kotak arsip berukuran kecil memiliki panjang $37 \mathrm{~cm}$, lebar $9 \mathrm{~cm}$, dan tinggi $27 \mathrm{~cm}$. Sedangkan kotak arsip yang berukuran besar memiliki panjang $37 \mathrm{~cm}$, lebar $19 \mathrm{~cm}$, dan tinggi $27 \mathrm{~cm}$. Arsip yang berbentuk odner, bundel tempel, binder, arsip gambar, atau jenis arsip lainnya, tidak perlu dimasukkan ke dalam kotak arsip, karena arsip tersebut dapat disimpan secara langsung atau dapat menggunakan sarana simpan lainnya. Arsip yang berbentuk folder, dan arsip tekstual dapat dimasukkan ke dalam sarana simpan berupa kotak arsip. Data digital disimpan pada Cartridge yang disusun dalam Roll O'pact. Arsip audio saat rapat di simpan dalam kaset pita yang disusun dalam sebuah almari.

e. Pemeriksaan kesesuaian DIK, pemeriksaan dilakukan oleh pejabat dari UP. Pemeriksaan bertujuan untuk mengklarifikasi antara DIK tercetak, DIK yang dilekatkan pada sarana simpan dan berkas arsip yang berada didalam kotak;

f. Pencetakan DAP, proses pemindahan arsip dilaksanakan dengan menggunakan daftar arsip yang akan dipindahkan ( selanjutnya disebut DAP). Pada DAP, pejabat UP (G4) memberikan pengesahan berupa tanda tangan rangkap 3. Untuk arsip yang telah diinput ke BI-RMS, otomatis tercetak Daftar Arsip Yang Akan Dipindahkan (DAP). Sedangkan arsip yang belum diinput dalam aplikasi, DAP dibuat secara manual sesuai dengan format yang berlaku;

g. Validasi dari pejabat UP, validasi dilakukan sebelum diajukan kepada pejabat SKA;

h. Validasi dari pejabat SKA, yaitu validasi persetujuan penerimaan berkas arsip yang akan dipindahkan dari unit pengolah ke Sentral Khazanah Arsip;

i. Menyegel dan memberi label segel dari UP, merupakan upaya menjaga kerahasiaan arsip dan memastikan bahwa arsip tersebut lengkap hingga tiba di Sentral Khazanah Arsip (SKA). Segel hanya dapat dibuka melalui persetujuan unit pengolah (UP) atau unit pemilik arsip. Pembukaan segel kotak arsip pun wajib dihadiri minimal satu orang saksi perwakilan dari unit pengolah (UP) atau pemilik arsip;

j. Pemberian paraf pejabat UP dan tanggal pada label segel kotak arsip atau sarana simpan lainnya;

k. Pemindahan berkas arsip dari unit pengolah (UP) ke Sentral Khazanah Arsip (SKA);

l. Penerimaan arsip oleh SKA, apabila jumlah yang diajukan untuk pindah kurang dari 10 maka petugas SKA akan menolak pemindahan. Setelah pemindahan 
disetujui, petugas SKA meregistrasi berkas arsip yang dipindahkan dengan menginput nomor kotak dalam aplikasi BI-RMS. Penerimaan arsip yang dipindahkan secara manual dilakukan dengan memverifikasi konsep DAP dan mengirimkan kembali kepada unit pengolah (UP). Selanjutnya, dilakukan sinkronisasi DIK dengan DAP dan mencatat arsip yang dipindahkan dalam Buku Tata Usaha Pemindahan Arsip. Proses selanjutnya adalah mencetak daftar arsip yang dipindahkan (DAP) rangkap dua dan pejabat SAK membubuhkan tanda tangan serta nama jelas pada DAP. Daftar arsip pindah dua rangkap yang telah dicetak tadi dikirimkan kepada pejabat UP untuk ditandatangani. Selanjutnya petugas SAK menyimpan DAP lembar-1 yang telah ditandatangani oleh pejabat UP.

m. Penyimpanan berkas arsip di lokasi simpan sesuai bentuk dan jenis arsip.

Apabila UP akan menarik kembali arsip yang telah dipindahkan, proses penarikan dilakukan dengan membuat daftar arsip yang ditarik kembali (selanjutnya disebut DATK). Petugas UP memperbaiki berkas arsip yang ditarik kembali dalam BI-RMS dan menyampaikan memorandum (M.01) kepada SKA terkait penarikan kembali arsip dengan dilampiri DATK. Tahap selanjutnya adalah pembuatan berita acara penarikan kembali arsip yang kemudian disimpan SKA.

Arsip yang ditarik kembali oleh UP umumnya disebabkan arsip menjadi arsip dinamis aktif kembali. Maksud dari "aktif kembali" yaitu arsip tersebut memiliki keterkaitan dengan proses administrasi yang sedang berlangsung. Apabila arsip tersebut dipinjam dengam hanya masa pinjam maksimal sesuai ketentuan yang berlaku (3 bulan), proses administrasi belum dapat diselesaikan. Oleh sebab itu, untuk efisiensi dan efektivitas penyelesaian proses administrasi, UP menarik kembali arsip yang telah dipindahkan dari SKA.

\section{Pemindahan Arsip Berbasis Aplikasi BI-RMS}

Bank Indonesia Records Management System (BI-RMS) adalah aplikasi yang berfungsi sebagai sarana pemberkasan melalui input berkas, penyimpanan, dan peminjaman yang mencakup pencarian arsip, persetujuan dan peminjaman arsip, kemudian pemindahan arsip dan pemusnahan arsip melalui menu pengelolaan arsip, serta pelaporan yang mencakup data informasi volume arsip satker. Aplikasi BI-RMS juga dapat membantu mencetakkan label arsip, daftar isi arsip, berita acara yang akan dimusnahkan, daftar arsip yang diserahkan, berita acara penilaian berkas serta pembuatan formulir, label, dan laporan volume arsip satuan kerja. Aplikasi tersebut digunakan oleh seluruh pegawai satuan kerja dan kantor perwakilan Bank Indonesia (KpwBI). Proses pemindahan arsip dengan basis aplikasi BI-RMS dapat dicermati pada gambar berikut:

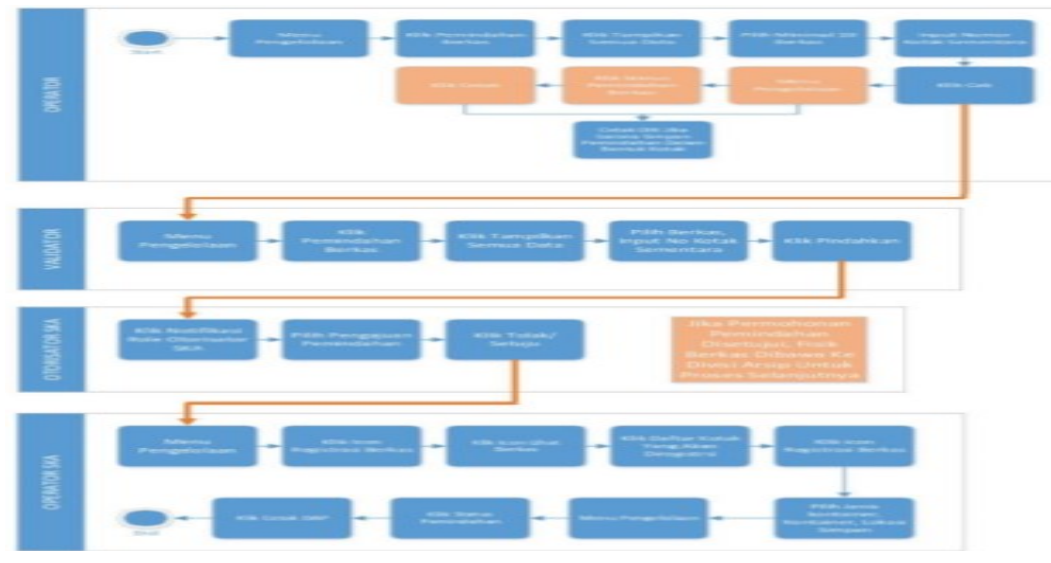

Gambar 3. Alur Pemindahan Arsip Berbasis BI-RMS 
Adapun tampilan awal dari aplikasi BI-RMS dapat dicermati pada gambar berikut:

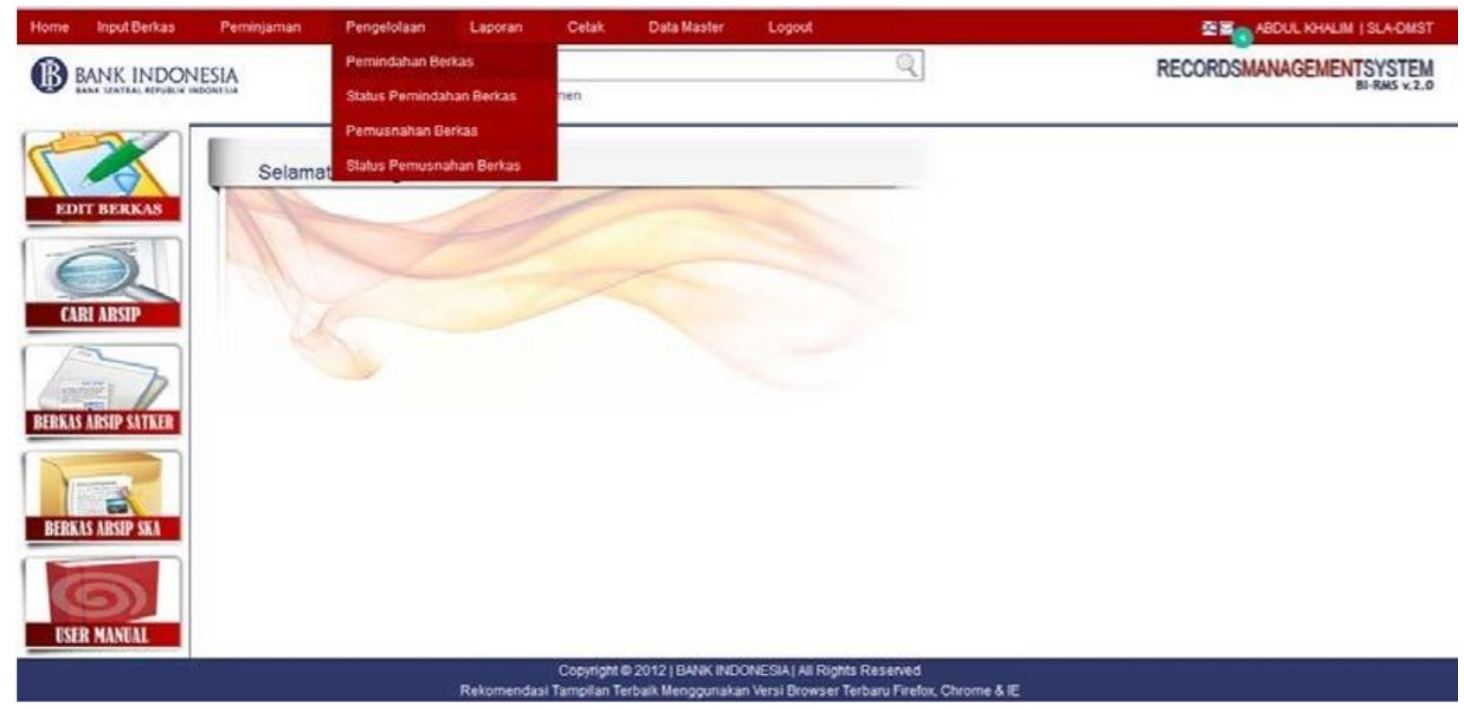

Gambar 4. Tampilan Awal BI-RMS

Untuk operasional aplikasi sebagai sarana pemindahan arsip, yaitu:

1. Pada halaman utama apliasi, klik menu "Pengelolaan", lalu klik menu "Pemindahan Berkas", selanjutnya klik menu "Tampilkan Semua Data". Saat semua data ditampilkan, pilih berkas yang akan dipindahkan ke Sentral Khazanah Arsip, minimal 10 berkas.

2. Setelah berkas arsip dipilih, berikan nomor kotak sementara, lalu tekan tombol "Cek". Contoh pemberian nomor kotak sementara dapat dicermati pada gambar berikut:

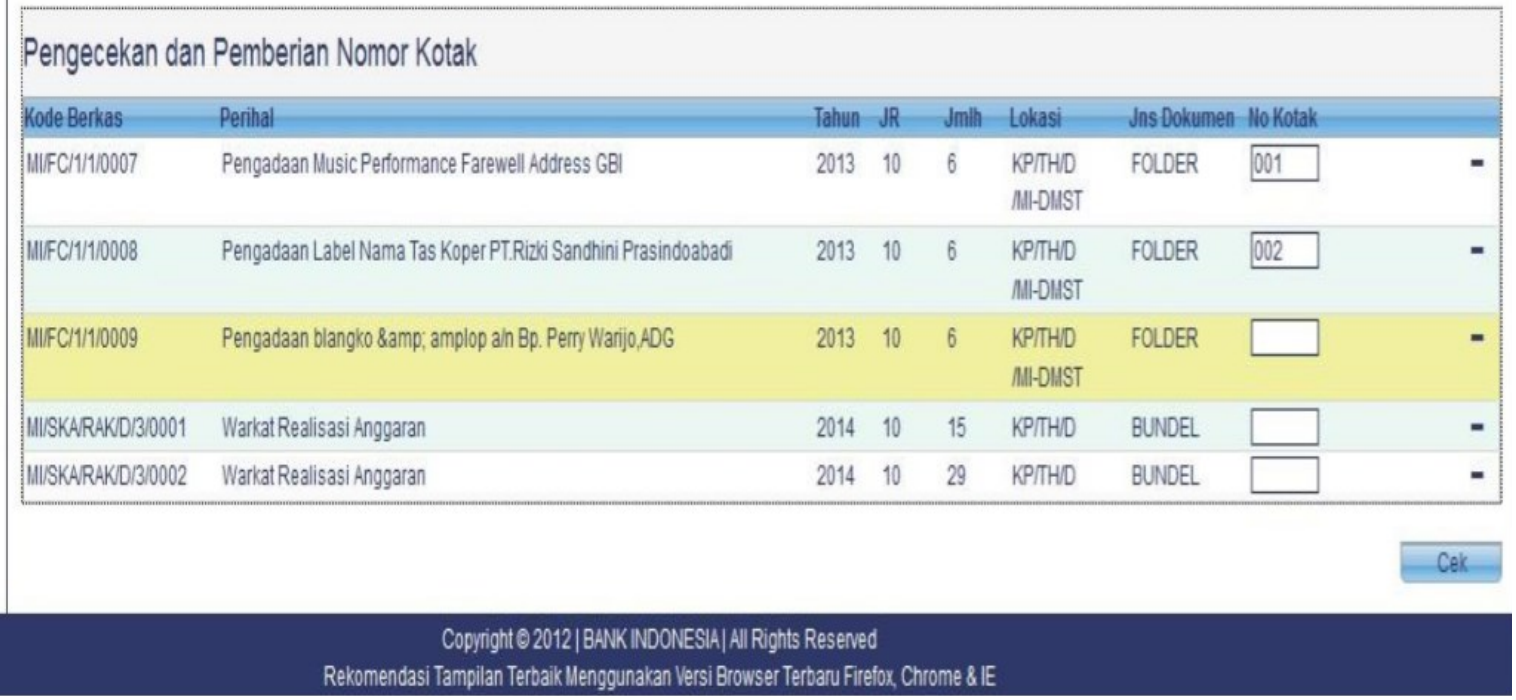

Gambar 5. Pengecekan dan Pemberian Nomor Kotak Sementara pada Aplikasi BI-RMS 
3. Mencetak DIK. Cetak Daftar Isi Kotak melalui menu "Pengelolaan", klik menu "Status Pemindahan Berkas", klik ikon "Printer" pada berkas yang akan dicetak DIK-nya. Untuk dapat mencetak, klik panah export file format menjadi pdf. Perhatikan gambar berikut:

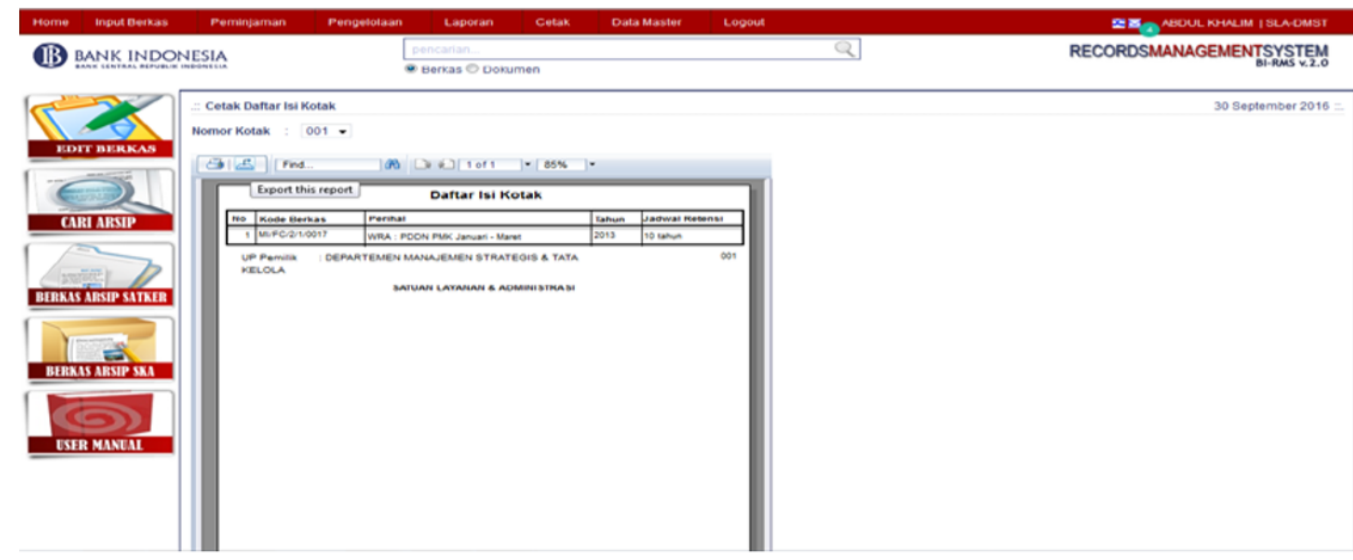

Gambar 6. Mencetak DIK pada Aplikasi BI-RMS

4. Persetujuan pemindahan, untuk memberikan persetujuan proses pemindahan, pada halaman utama user Validator, klik menu "Pengelolaan", lalu klik "Pemindahan Berkas", dan klik "Tampilkan Semua Data". Pilih berkas yang sudah dicek fisiknya dan diberi nomor kotak sementara seperti pada gambar berikut:

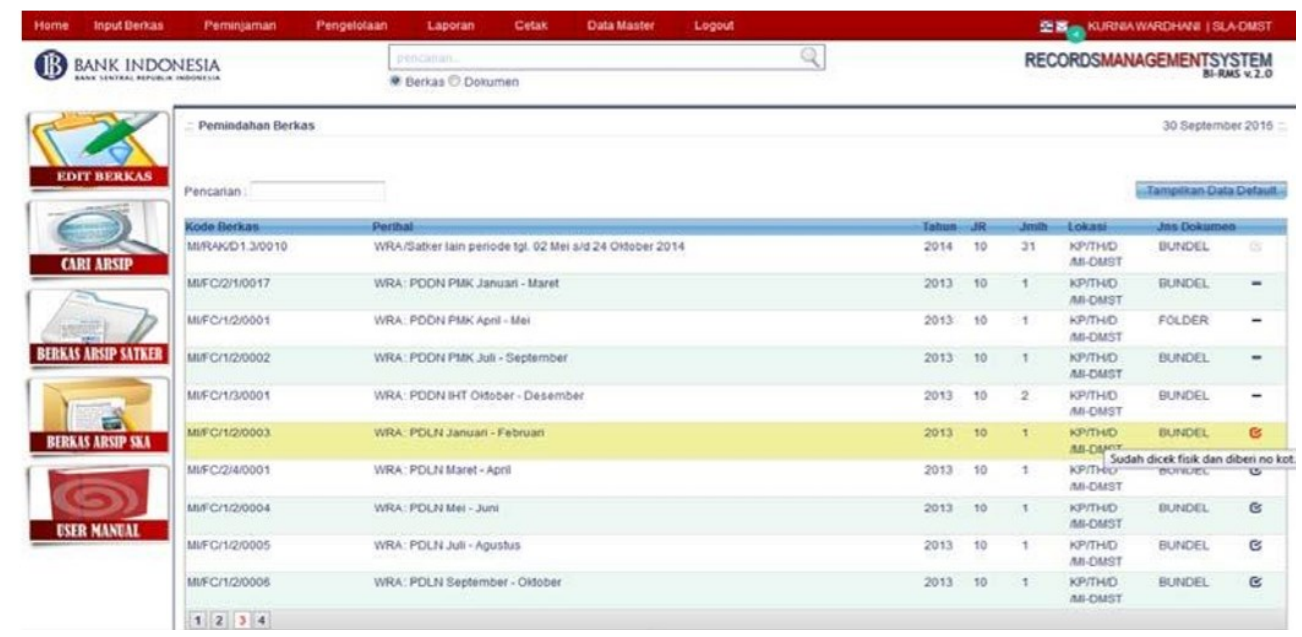

Gambar 7. Pemilihan Berkas Arsip yang Dipindahkan pada Aplikasi BI-RMS

Pada berkas yang akan dipindahkan, klik "Pindahkan". Berkas arsip yang telah di pilih akan berubah menjadi tanda (-), sebagaimana gambar berikut

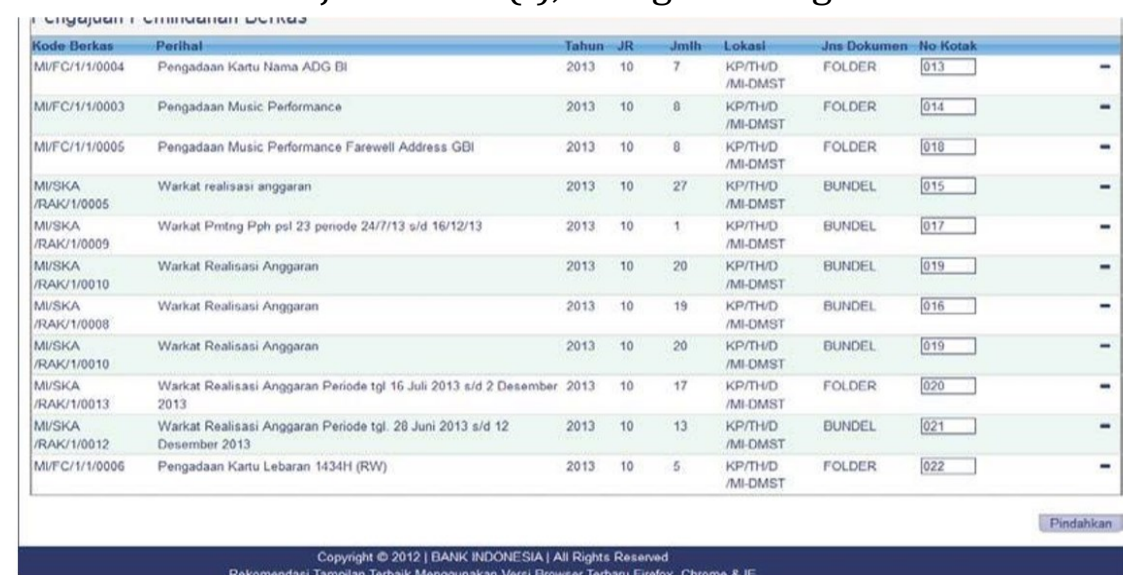

Gambar 8. Tampilan Berkas Arsip yang telah Dipili 
Selanjutnya akan muncul kotak pesan "Permohonan pemindahan berkas telah diajukan, tunggu konfirmasi dari SKA", kemudian tekan tombol "oke" pada pesan tersebut.

5. Untuk konfirmasi dari SKA, pada halaman utama Otorisator SKA, klik tombol "Role Otorisator SKA". Petugas SKA memilih user yang mengajukan pemindahan dokumen. Setelah dilakukan persetujuan pemindahan, muncul pesan "Validasi Pemindahan Berkas Berhasil !!", klik "oke".

6. Petugas UP membawa fisik berkas arsip yang akan dipindahkan ke Divisi Arsip.

7. Pada halaman utama Operator Sentral Khazanah Arsip (SKA), klik menu "Pengelolaan", lalu klik "Registrasi Berkas", tekan ikon - Lihat Berkas.

8. Meregistrasi pada daftar kotak yang akan diregistrasi dengan menekan ikon Registrasi Berkas, seperti pada gambar dibawah ini

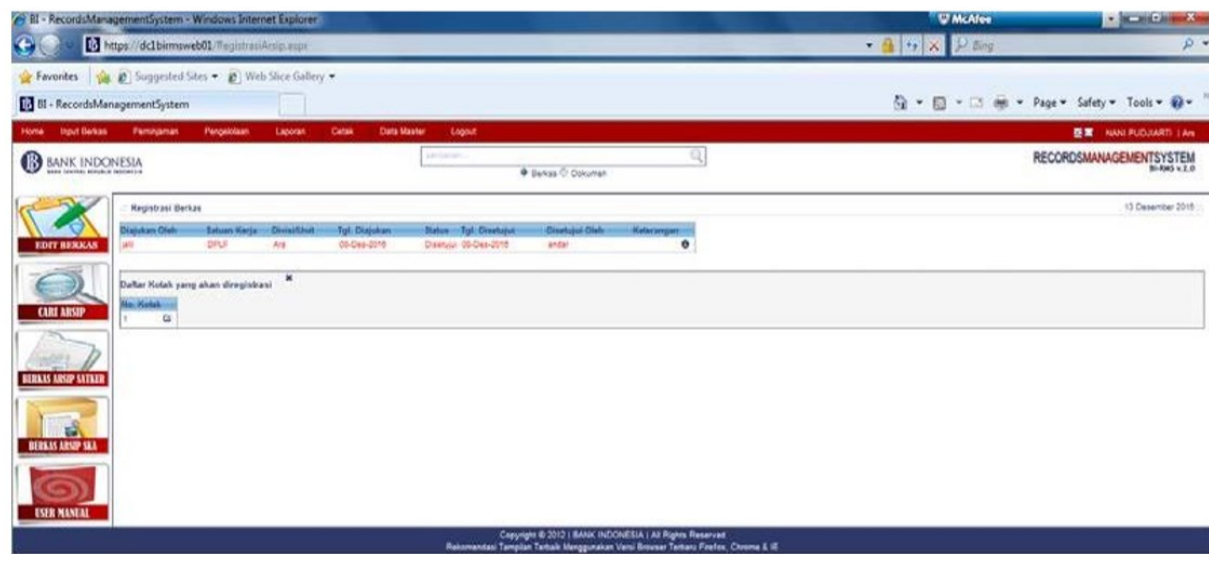

Gambar 8. Registrasi Berkas Arsip yang akan Dipindahkan pada Aplikasi BI-RMS kas Arsip yang Dipindahkan pada Aplikasi BI-RMS

Jika dicermati pada gambar 7, kolom "Diajukan Oleh" telah terisi nama pegawai yang mengajukan yaitu Adi, kolom "Satuan Kerja" terisi satuan kerja DPSI, kolom "Divisi Unit" terisi oleh Ars yang berarti Divisi Arsip. Selanjutnya, kolom "Tgl Diajukan" terisi tanggal 6 Desember 2016, kolom "Berkas" terisi dengan validasi yaitu disetujui, kolom "Tgl Disetujui" terisi tanggal 8 Desember 2016 dan kolom "Disetujui Oleh" terisi atas nama Andar.

9. Setelah berkas arsip berhasil diregistrasi, kemudian pilih jenis container dengan cara klik ikon "Kontainer" untuk nomor kontainer, dan "Lokasi Simpan" untuk lokasi berkas arsip akan disimpan, klik "Simpan”. Cermati pada gambar dibawah ini:

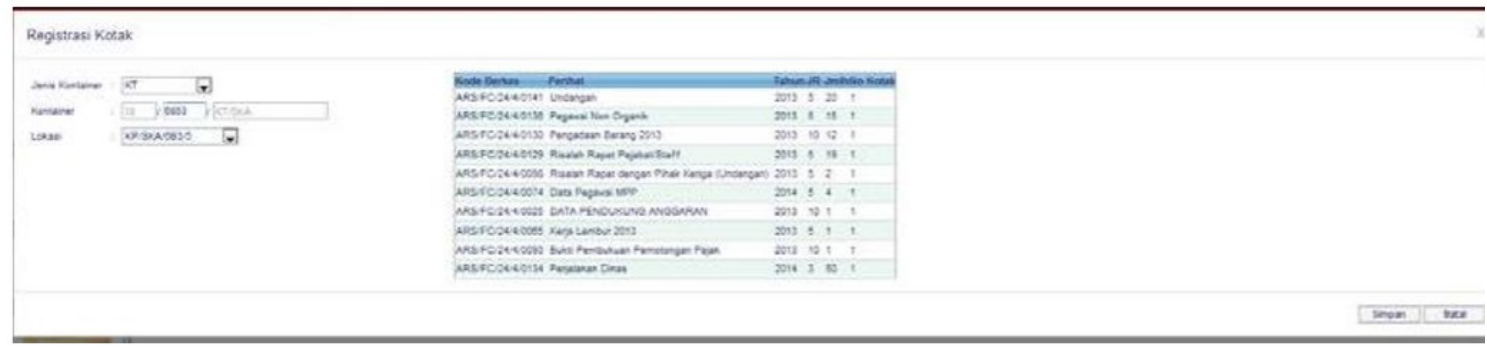

Gambar 9. Penyimpanan Berkas Arsip yang Dipindahkan pada Aplikasi BI-RMS

Cara pengisiannya, yaitu:

a. kolom "Jenis Kontainer" diisi dengan KT

b. kolom "Kontainer" diisi oleh 18/0833/KT

c. kolom "Lokasi” diisi oleh KP/SKA/C83/3. 
10. Setelah disimpan, pada menu "Pengelolaan", klik "Status Pemindahan". Daftar arsip yang akan dipindahkan muncul sesuai dengan berkas arsip yang telah dipilih. Langkah selanjutnya adalah cetak Daftar Arsip Yang Dipindahkan (DAP) sebagaimana terlihat di bawah ini :

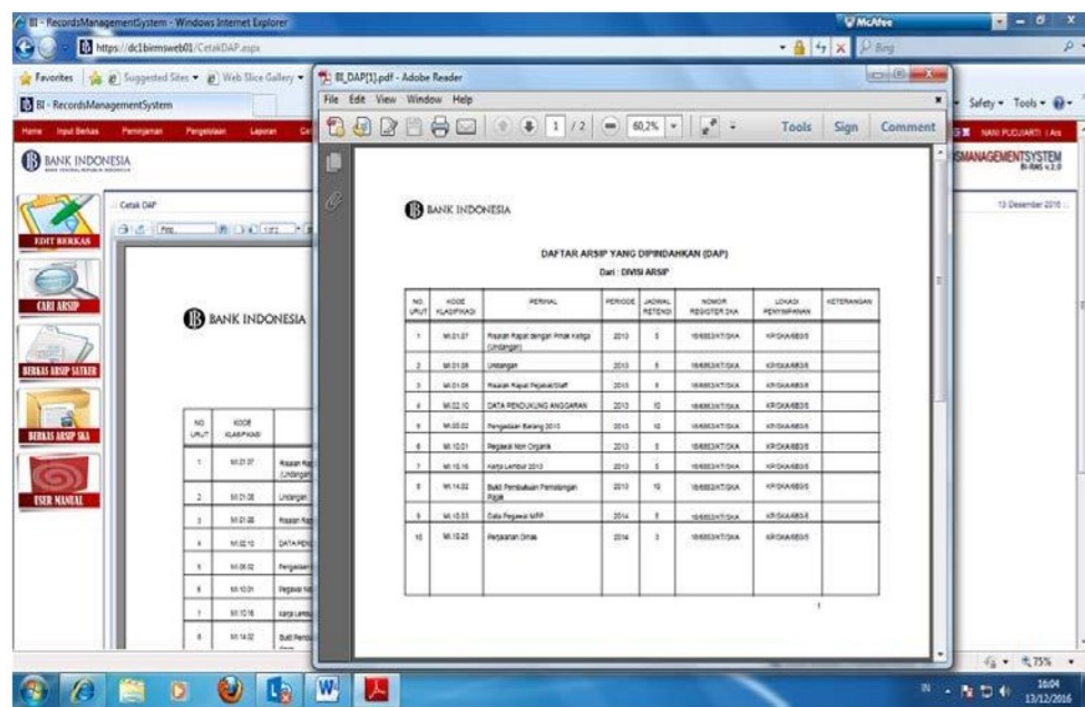

Gambar 10. Daftar Arsip yang akan Dipindahkan (DAP) pada Aplikasi BI-RMS

Berdasarkan gambar 10, Daftar Arsip yang akan Dipindahkan (DAP) terdapat beberapa kolom, antara lain kolom "No Urut", "Kode Klasifikasi", kolom "Perihal", kolom "Periode" terisi 2015, kolom "Jadwal Retensi”, kolom "Nomor Registrasi SKA", serta kolom "Lokasi”.

Divisi Arsip Bank Indonesia juga memiliki aplikasi BI-SASKA atau Bank Indonesia Sistem Aplikasi Pengelolaan Arsip Sentral Khazanah Arsip. Aplikasi tersebut berfungsi untuk memudahkan pencatatan pemindahan dan penemuan kembali arsip di Sentral Khazanah Arsip (SKA). BI-SASKA digunakan pada proses input data dalam penyusunan daftar arsip yang dipindahkan (DAP). Input data hanya dapat dilakukan oleh divisi arsip. Adapun hak akses aplikasi BI-SASKA dibatasi hanya untuk manajer, staff, dan tenaga outsourcing yang khusus ditunjuk.

Semua daftar arsip yang dipindahkan (DAP) harus di entry ke dalam aplikasi BI-SASKA. Aplikasi BI-SASKA juga terkoneksi dengan BLINK (Bank Indonesia Layanan Internet Kerja). Dengan demikian, seluruh daftar arsip yang dipindahkan yang telah diinput ke dalam aplikasi BI-SASKA dapat diakses oleh seluruh pegawai kantor pusat Bank Indonesia (KP BI) melalui Bank Indonesia Layanan Internet Kerja (BLINK) tersebut.

Aplikasi BI-SASKA membantu Bank Indonesia melaksanakan tiga kegiatan dalam proses pemindahan arsip, yaitu penerimaan arsip, penyelesaian penerimaan, dan pembuatan laporan. Adapun tahapan pengadministrasian pemindahan arsip inaktif menggunakan aplikasi Bank Indonesia Sistem Aplikasi Sentral Khazanah Arsip (BI-SASKA) dapat dicermati pada bagan berikut:

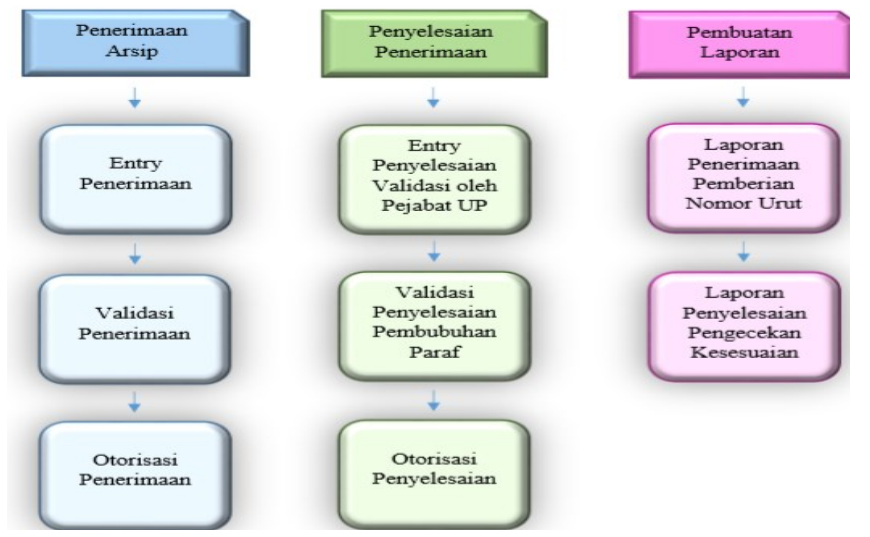

Bagan 2. Alur Pengadministrasian Pemindahan Arsip Inaktif Berbasis BI-SASKA 
Apabila dijabarkan lebih detail, maka proses pengadministrasian pemindahan arsip berbasis BI-SASKA, terdiri dari:

1. Penerimaan arsip, setelah SKA menerima DAP, kemudian dilakukan entry DAP ke dalam aplikasi BI-SASKA. Lembar entry akan dicetak dan disematkan pada halaman paling depan DAP untuk memberikan keterangan dan kode terkait dengan DAP. Data yang harus dilengkapi dalam Data Penerimaan DAP, yaitu kode satker, tanggal DAP, jenis arsip, kode DAP, tanggal terima, jumlah DAP, lokasi DAP, nama petugas penerima, nama pejabat penandatangan, keterangan, nama petugas entry data dan tanggal entry. Tahap validasi penerimaan dilakukan data data yang dientry telah dipastikan kebenarannya sesuai dengan Daftar Arsip Yang Dipindahkan (DAP). Kegiatan otorisasi tersebut hanya dapat dilakukan oleh pejabat SKA. Otorisasi dilakukan dengan mensinkronkan data yang ada pada DAP dengan data yang ditampilkan di form otorisasi. Pejabat SKA atau pejabat yang berwenang melakukan otorisasi memberi tanda pada tick box sesuai dengan data yang ada.

2. Penyelesaian penerimaan, penerimaan penyelesaian berfungsi melakukan kegiatan penambahan data atau entry data, edit data, dan penyelesaian kegiatan entry data. Pilih menu "Penyelesaian" kemudian pilih sub menu "Lihat Data" atau "Edit/Lihat Data". Tahap selanjutnya yaitu memilih jenis arsip dan kode Daftar Arsip yang Dipindahkan (DAP) untuk di entry. Setelah menemukan jenis arsip dan kode DAP nya, klik ikon "Tambah Data". Cermati gambar berikut:

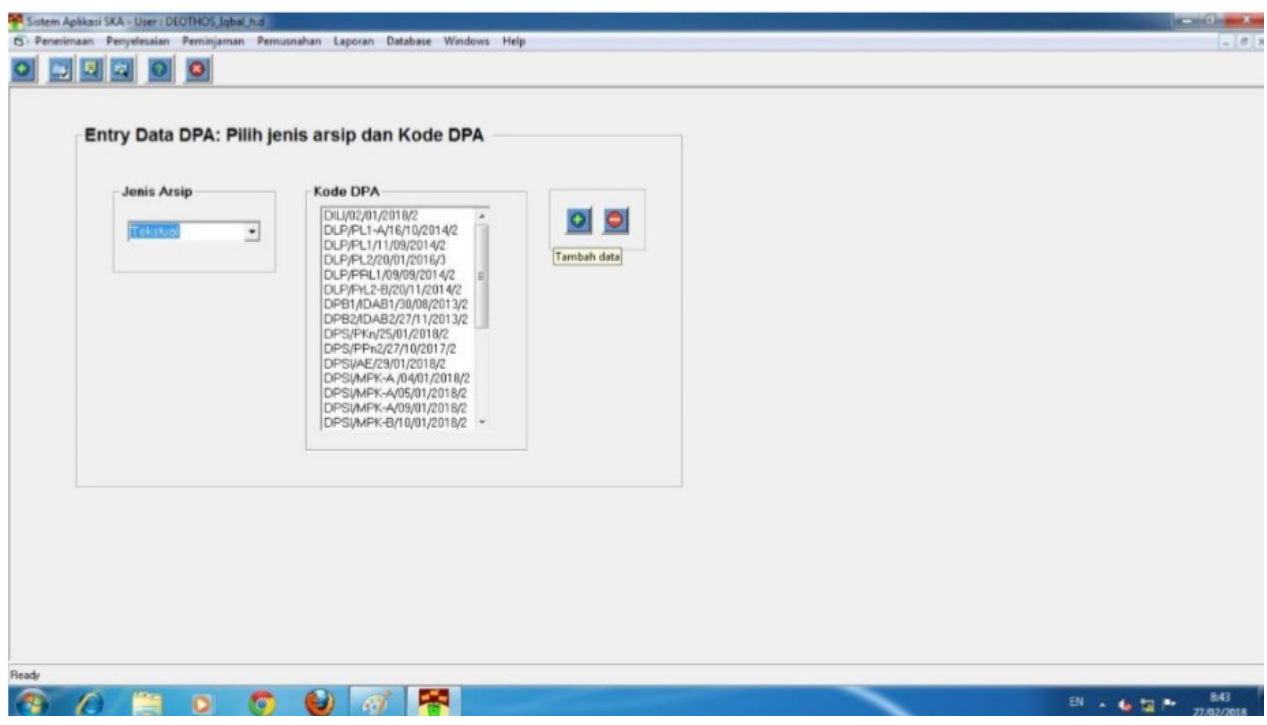

Gambar 11. Menu Entry Data DAP untuk Penambahan atau Penginputan Data

3. Tahap selanjutnya, saat menekan ikon "Tambah Data” muncul kolom pengisian data DAP. Adapun data yang harus diisi, yaitu: Klasifikasi, Masalah, Periode Arsip, Jenis Arsip, Jumlah Arsip, Keterangan, No Kotak, No Folder, Kode Arsip, Kode Lokasi Simpan, Lantai, Blok, Unit, Kolom. Setelah terisi semua, klik ikon "ceklist warna hijau" untuk menyimpan data yang telah di entry. Langkah selanjutnya adalah penyelesaian data. Penyelesaian data ini dapat dilakukan dengan memilih menu "Penyelesaian" dan memilih sub menu "Entry Data Selesai". Pada menu penyelesaian, pilih jenis arsip dan kode DAP yang akan dilakukan penyelesaian data. Lalu, klik "ceklist warna hijau" hingga muncul pesan yang menampilkan kode DAP dan jumlah data yang telah diinput, kemudian klik "Yes".

4. Tahap selanjutnya, yaitu klarifikasi kembali data DAP yang telah diinput dan memastikan data yang telah diinput sudah sesuai. Selanjutnya, simpan data tersebut dengan cara klik ikon "simpan".

5. Validasi penyelesaian, tahap ini dilakukan setelah data yang dientry sudah dipastikan kebenarannya dan sesuai dengan Daftar Arsip yang Dipindahkan (DAP) yang ada. Otorisasi hanya dapat dilakukan oleh Sentral Khazanah Arsip (SKA) dengan cara 
mensinkronkan data yang ada pada Daftar Arsip yang Dipindahkan (DAP) dengan data yang ditampilkan pada form otorisasi. Pejabat SKA atau pejabat yang berwenang melakukan otorisasi dengan memberi tanda pada tick box sesuai dengan data yang ada.

6. Pelaporan, terdapat dua jenis laporan, yaitu laporan penerimaan dan laporan penyelesaian.

\section{KESIMPULAN}

Program penyusutan arsip yang dilakukan oleh Bank Indonesia didasarkan pada kebijakan, yaitu UU nomor 43 tahun 2009 tentang Kearsipan, PP nomor 28 tahun 2012 tentang Pelaksanaan UU nomor 43 tahun 2009 tentang Kearsipan, UU nomor 8 tahun 1997 tentang Dokumen Perusahaan, UU nomor 87 tahun 1999 tentang Tata Cara Penyerahan dan Pemusnahan Dokumen Perusahaan, UU nomor 23 tahun 1999 tentang Bank Indonesia, Peraturan Dewan Gubernur No. 10/10/PDG/2008 tentang Manajemen Informasi Bank Indonesia, Surat Edaran Bank Indonesia No. 18/125/INTERN tahun 2016 tentang Manajemen Dokumen Bank Indonesia serta ISO 15489 Records Management Bank Indonesia.

Program penyusutan arsip di Bank Indonesia terdiri dari pemindahan, pemusnahan, dan penyerahan. Kegiatan pemindahan arsip dilaksanakan dari unit pengolah (UP) ke unit kearsipan, pada Bank Indonesia disebut dengan Sentral Khazanah Arsip. Prosedur pemindahan ialah bagi arsip yang memiliki retensi diatas tiga tahun atau permanen. Kegiatan pemindahan dapat dilakukan pada aplikasi BI-RMS.

untuk mempermudah penyusutan arsip di Bank Indonesia, dibutuhkan inovasi serta pembaharuan secara berkala, khususnya aplikasi yang digunakan oleh Bank Indonesia dalam mengelola arsip. Pembaharuan penting dilakukan karena tuntutan perkembangan zaman dan dapat mempermudah pekerjaan. Pembaharuan aplikasi ini juga ditujukan agar dalam penggunaannya dapat berjalan secara efektif dan efisien. Pada proses pemindahan misalnya saja, data yang telah terinput di aplikasi BI-RMS, Daftar Arsip yang Dipindahkan (DAP) tidak perlu lagi diinput ke dalam aplikasi BI-SASKA, namun terintegrasi dan dapat memunculkan daftar arsip yang dipindahkan.

\section{DAFTAR PUSTAKA}

Sugiarto, Agus dan Teguh Wahyono. (2005). Manajemen Kearsipan Modern Dari Konvensional ke Basis Komputer. Yogyakarta: Penerbit Gava Media.

Barthos, Basir. (1997). Manajemen Kearsipan Untuk Lembaga Negara, Swasta dan Perguruan Tinggi. Jakarta: Bumi Aksara.

Martono, Boedi. (1997). Penyusutan Dan Pengamanan Arsip Vital Dalam Manajemen Kearsipan. Jakarta: Pustaka Sinar Harapan.

Adi, Rianto. (2004). Metodologi Penelitian Sosial dan Hukum. Jakarta:Girani

Muhidin, Sambas Ali dan Hendri Winara. (2016). Manajemen Kearsipan untuk Organisasi Publik, Bisnis, Sosial, Politik, dan Kemasyarakatan. Bandung: CV Pustaka Setia.

International Standard Organization, IS0 15489:1: Information, Documentation and Records Management. (Switzerland : International Standard Organization, 2016).

Keputusan Kepala ANRI Nomor 7 tahun 2001 tentang Pedoman Penilaian Arsip bagi Instansi Pemerintah, Badan Usaha dan Swasta

Peraturan Dewan Gubernur No. 10/10/PDG/2008 tentang Manajemen Informasi Bank Indonesia

Peraturan Pemerintah Nomor 28 tahun 2012 tentang Pelaksanaan UU No. 43 tahun 2009

Petunjuk Penggunaan Bank Indonesia Records Management System (BIRMS) v.2.0, Bank Indonesia, 2017, 
PP No. 87 tahun 1999 tentang Tata Cara Penyerahan dan Pemusnahan Dokumen Perusahaan.

SE No. 18/125/INTERN tanggal 30 Desember 2016 tentang Manajemen Dokumen Bank Indonesia.

Undang-Undang Nomor 8 Tahun 1997 tentang Dokumen Perusahaan

Undang-Undang Nomor 23 Tahun 1999 tentang Bank Indonesia

Undang-Undang Nomor 43 Tahun 2009 tentang Kearsipan 